Nel H \& Roestenburg $W$

\title{
ASSESSMENT OF A COMMUNITY: PROMOTING AN EQUITABLE SOCIETY THROUGH INCLUSION AND EMPOWERMENT
}

Prof Hanna Nel and Dr Wim Roestenburg, Department of Social Work, Rand Afrikaans University Auckland Park.

\section{ABSTRACT}

To adhere to the new developmental welfare policy of South Africa, the Department of Social Work at the Rand Afrikaans University (South Africa) in co-operation with the African SelfHelp Association (ASHA), a non-profit organisation, conducted a needs assessment for Soweto among all the families connected with the 40 preschool crèches of ASHA. Findings from participatory action research indicated a need for four different programmes: programmes for preschool children; programmes to enhance community leadership; family enrichment programmes; and special delivery programmes regarding HIV/AIDS, disability, crime and violence, illiteracy, poverty alleviation and substance abuse. Through the principle of inclusion, people took ownership of these programmes, which in turn had an empowering effect on them.

\section{INTRODUCTION}

The winds of change, democratisation and liberation constantly provide opportunities for communities, government and non-governmental organisations in the social welfare sector to find creative and innovative ways to adjust to, and find ways of, improving services in the community. Such institutions have to position themselves by dealing with issues related to equity, empowerment and self-help in order to maintain their place and recognition in the communities they serve.

Segregation and paternalism characterised social service delivery in the apartheid South Africa. These symptoms resulted in an outright rejection of services, despondence, disempowerment and lack of participation by community members. One organisation that managed to maintain credibility in the community and is now expanding its operations is the African Self-Help Association (ASHA). This paper deals with the process and results of a community needs assessment project that was undertaken collaboratively between the Department of Social Work at the Rand Afrikaans University (RAU). Besides reporting on the findings from an extensive survey in several communities of Soweto, the largest African township in South Africa, guidelines are provided on how surveying can be used as a tool to promote equity, empowerment and self-help in the community development process.

\section{BACKGROUND OF ASHA}

In the early days of the Nationalist apartheid government in South Africa, ASHA started its work in Soweto as an outreach community support effort by a group of concerned liberal white women who had access to funding resources. Known as "helpers", these women worked in collaboration with African women of the area to relieve poverty and provide support to African women who come to the cities to work. During the 1950s several childcare centres (crèches) were started to look after the children of working mothers. Initially started at private homes, these day nurseries soon developed into formal day-care centres (Haggie, 1994). Since 1954 the number of crèches 
has grown from 29 to 40 specialised, fully furnished care centres, employing 320 permanent staff and offering a broad range of services to the community.

Guided by the new social welfare policy in South Africa, ASHA developed a new vision for the future in 1999. This policy is geared towards the building of "...a self-reliant nation in partnership with all stakeholders through an integrated social welfare system which maximizes its existing potential and which is equitable, sustainable, accessible, people-centred and developmental in nature" (Government Gazette, 1999). This policy envisions the concept of one-stop centres that promote an enabling and caring society, where specific groups such as children "... are guided towards competency and an experience of well-being." Working towards this goal ASHA's vision is now "...to improve the quality of life of pre-school children and their families by building their capacities through an integrated and sustainable development programme”.

To develop this vision required programmes that would facilitate the achievement of the objectives associated with the vision and extensive needs assessment involving the consumers of their services, parents and families. From this assessment service plans would be developed for each crèche to guide it in its new direction.

\section{OBJECTIVES OF THE STUDY}

The vision of ASHA was to improve their functioning in the target community. The goal of the research was to support the development of the organisation by means of a thorough community assessment.

The objectives were formulated as follows:

- to conduct a needs assessment in the area where crèches are operational;

- to promote community ownership by involving as many inhabitants as possible;

- to develop service plans that will ensure the growth and expansion of ASHA activities; and

- to determine critical areas for social intervention.

\section{THE CONTEXT OF THE NEEDS ASSESSMENT STUDY}

The collaboration between ASHA and RAU included three researchers from RAU and 18 undergraduate Social Work students. The study was conducted on both a qualitative and quantitative level and would follow a participatory action research strategy. A qualitative study promoted the collection of rich qualitative data, the principle of all inclusiveness and maximal participation, whilst a quantitative study would ensure thorough knowledge of the community, facilitate scientific objectivity and ensure the quantification of needs (Berg, 1995; Bless \& HigsonSmith, 1995).

The survey was conducted at each crèche during a series of special parent information days. The study would be done in an African community context, which meant that some contextual issues would apply, which required cultural-sensitive management.

\section{ISSUES IN PLANNING THE PROJECT}

A stated condition for the project was that participation should be all inclusive. This meant that any form of sampling would not be acceptable, as this would promote a perception of exclusion (Burkey, 1993). In a sense this condition represents a case of the sample and the population being the same. With \pm 3800 preschool children distributed over forty crèches, a research strategy had to 
be adopted that would not become too expensive in financial and logistical terms, yet ensured inclusion and scientific validity.

A further consideration was that many parents in the target community are illiterate and would not be able to complete a questionnaire. Stemming from perceptions developed during the previous political era, there was a possibility of resistance to providing written information. A methodology was worked out that would, at best, include this contextual limitation.

\section{RESEARCH METHODOLOGY AND INSTRUMENTATION}

As a result of the set conditions, it was decided to use a participatory action research strategy, where the population being studied is actively involved in developing solutions for the social problems they experience (Creswell, 1994; Schurinck in De Vos, 1998). The research findings would be fed back to the community as part of a solution in a joint problem-solving process (Marshall \& Rossman, 1995).

The need for quantification of the results necessitated the use of a questionnaire. Field workers would complete these as an interview schedule, using a pictorial scale format, where respondents were illiterate, to improve the validity of responses. The questionnaire was developed in collaboration with ASHA representatives during focus groups that were held on two Saturdays with groups of management staff representatives of each crèche. In this way maximum participation from the target population was ensured and the issues that were taken up in the questionnaire represented the most prominent concerns of the target population.

The instrument was prepared in such a way that data scanning could be done - a necessary requirement in such a large-scale project. The computer software program, Formic, was used to scan the data. The research was conducted over a six-month period and a sample of 1790 was realised.

\section{QUANTITATIVE RESULTS OF THE SURVEY}

Main findings from each section of the survey are provided in the following discussion. The data will be primarily compared with a study done in the Department of Sociology at the University of the Witwatersrand, Johannesburg, and edited by Morris (1999). This study was conducted in January 1997, where 3000 interviews were conducted with the breadwinners of households in Soweto.

\section{Family demographics}

Gender: The sample consisted of $78 \%$ females and $22 \%$ males. Although the sampling strategy followed could at best be described as accidental, this distribution bears a slight resemblance to the estimated spread of the population of ASHA, which consists of 1688 males and 3127 females (ASHA introductory document to business plans, 1999). From these statistics one can come to the conclusion that mothers and the extended families are more involved in the activities of the crèches and thus in their children's lives.

The population of ASHA differs from the population of Soweto, where the female population was 51,8\% and the male population 48,2\% (Morris, 1999:26).

Age: The mean age of the sample is 34.29 , with the mean of the youngest group at 29.20 and the mean of the eldest group at 40.20. This indicated that the parents involved in the project are in stage 3 - the family with young children stage - of development (Carter \& McGoldrick, 1989:15). 
It also indicted that grandparents and family members are involved in the upbringing of these preschool children.

Household size: The mean household size of the current family is 6.23 , with the mean of the group with the largest families being 8.46. These statistics correlated with the whole of Soweto, where an average of 6,4 people per stand was found (Morris, 1999:5).

The mean value of the number of men and women older than 18 years of age in the current household is 2.05 and 2.38, suggesting that a significant number of families in the sample are of the extended type.

Educational level: One quarter of the breadwinners $(25 \%)$ of the households possess an educational level of Grade 12, whilst $16 \%$ have an education below Grade 9. Only $18 \%$ have a tertiary qualification. Thus more than half of the sample (57\%) had a qualification below Grade 12, suggesting a low level of education and subsequent high potential for poverty and unemployment. This characteristic explains why $95 \%$ of children in crèches are subsidised by the government, whilst the remaining 5\% are financially supported by the ASHA distress fund (ASHA introductory document to business plans, 1999).

Comparing the above-mentioned findings with the study of the University of the Witwatersrand, it was found that $64,6 \%$ of the Sowetans' qualifications are between Grade 7 and 12, and about a quarter had a maximum qualification of Grade 6 (Morris, 1999:9). In comparison with the 18\% of the people connected with ASHA who had a tertiary qualification, only 8,5\% of the whole of Soweto had tertiary qualifications (Morris, 1999:9).

The 1996 census found that (nationally) $24,3 \%$ of the African population above the age of 20 had no education and another $27,8 \%$ had some primary schooling or had only completed primary schooling (Statistics South Africa, 1998). In comparison to Soweto, the figures look much better.

Language: $42 \%$ of respondents are Zulu speaking, 20\% Southern Sotho and 15\% Tswana. Although the other local languages are also represented in the sample, it is significant to note the ethnic distribution of the population.

Marital status: $41 \%$ of the respondents are married to their first partner, whilst $37 \%$ were never married; $10 \%$ of respondents are without marital partners and are thus single parents. These statistics indicate that the percentage of single parents or female-headed households is about equal to the number of households characterised by marriage.

Position in household: $56 \%$ of respondents are mothers, $16 \%$ fathers and $24 \%$ occupy other positions in the household. This indicates a gender bias, but also illustrates the large part played by family members in supportive roles. The above-mentioned statistics lead to various conclusions, namely that the mothers connected to ASHA are more involved in the upbringing of their children than the fathers, that family members are more involved in the lives of the children who are in the ASHA centres than the fathers, and that mothers and family members are more actively involved in the ASHA centres than the fathers.

Housing: The majority of respondents are living in private houses (76\%), whilst $13 \%$ live in outside rooms adjacent to houses. These figures suggest that this area has been reached by housing developments and that many of the families connected to ASHA centres live in private houses.

Occupational status: With regard to males, $14 \%$ were never employed, $12 \%$ work in the skilled artisan sector, $11 \%$ are transport and communication workers and $11 \%$ are unskilled. Regarding females, $19 \%$ were never employed, $16 \%$ were in administrative posts, $13 \%$ in secondary 
professions and $10 \%$ in the services sector. From these statistics most of the respondents fell into the categories of unskilled and semi-skilled employment.

\section{Involvement in community issues}

In this section mean scores were interpreted according to a five-point scale. The results are recorded in Table 1.

TABLE 1

INVOLVEMENT IN COMMUNITY ISSUES

\begin{tabular}{|l|l|l|l|}
\hline COMMUNITY ISSUES & MEAN & STD DEV & N \\
\hline Involved in church group & 3.32 & 1.58 & 1712 \\
\hline Involved in sports club & 1.95 & 1.36 & 1514 \\
\hline Involved in cultural club & 1.65 & 1.19 & 1443 \\
\hline Use library & 2.45 & 1.50 & 1526 \\
\hline Worry about community & 4.26 & 1.25 & 1590 \\
\hline Involved in improvement of community & 3.25 & 1.64 & 1497 \\
\hline Want to become more involved & 4.08 & 1.33 & 1531 \\
\hline Community is safe environment & 2.00 & 1.32 & 1537 \\
\hline
\end{tabular}

With regard to community issues, it is clear from the above table that the respondents often worry about the community, and they also state that they have often thought about becoming more involved in the community. However, none of these issues indicated direct involvement in the community. With regard to active involvement, the respondents indicated that they were involved in the improvement of their community half of the time and they also indicated that they were involved in church groups half of the time. The rest of their involvement in sports clubs, the cultural club, the use of the library seems to be seldom. With this index it was possible to analyse means to determine areas where more or less community concern and involvement occurred. It seemed as if the respondents are involved in the development of their community half of the time and wanted to become more involved, but did not have the knowledge and skills.

\section{Most prominent needs experienced}

In this section respondents were given a list of fourteen possible programmes to select from by means of a Yes or No answer. These programmes ranged from family-focused programmes, lifestyle programmes for employment and small business development programmes. From the responses it became clear that most of the respondents wanted to participate in parental skills programmes and job-finding programmes. Reading and writing skills were the least popular. All crèches, except eight, indicated that their biggest need was for the improvement of their parental skills. This was followed in two areas by job-finding skills, whilst in six cases employment was the highest.

In terms of infrastructure development, the need for computer centres was most prominent. This was followed by more clinics (health care) and then libraries.

\section{QUALITATIVE DATA ANALYSIS}

Analysing qualitative data from 1790 interviews requires special logistical arrangements. Teams of students were employed to conduct the analysis after being trained in analysis techniques. Data 
were analysed from the raw state, question by question, by physically separating questions from the questionnaire. In this way initial categorisation was introduced from which further analysis could be conducted (Denzin \& Lincoln, 1994).

The following techniques were used in the process, as proposed by Giorgi (1985), Kerlinger (1986) and Tesch (in Cresswell, 1994). The steps were as follows:

Step 1: Data (the reports of all the focus groups and comments on all the qualitative questions of the questionnaires, and field notes were read and coded by the researchers separately.

Step 2: The researchers identified major sub-categories reflected in the data.

Step 3: The researchers then identified units of meaning that related to major and sub-categories.

Step 4: Relationships between major and sub-categories were identified and reflected as themes.

Step 5: Consensus discussions between the researchers and an independent expert were held. A literature search was conducted to identify this study's similarities, differences and contributions with that of previous research.

Needs and problems were identified according to the following themes and categories, namely direct service: preschool crèches' needs; community leadership needs; family needs; and special needs (see Table 2).

Recommendations are also made on the grounds of the above-mentioned needs and problems.

TABLE 2

NEEDS AND PROBLEMS: QUALITATIVE DATA

\begin{tabular}{|l|l|l|l|}
\hline \multicolumn{1}{|c|}{$\begin{array}{c}\text { Direct service: } \\
\text { preschool needs }\end{array}$} & \multicolumn{1}{c|}{$\begin{array}{c}\text { Community } \\
\text { leadership needs }\end{array}$} & \multicolumn{1}{|c|}{ Family needs } & \multicolumn{1}{|c|}{ Special needs } \\
\hline Preschool children & Lack of effective & Roles, structures and & HIV/Aids \\
Personnel & leaders & relationships & Disability \\
Physical aspects & Characteristics and & Enhancement of life & Crime and \\
Parents & qualities of leaders & skills and values & violence \\
& needed & Health issues & Illiteracy \\
& Skills of leaders & Educational needs & Poverty \\
& & & Substance abuse \\
\hline
\end{tabular}

\section{Theme 1: Direct service needs}

Four main categories of needs are identified regarding the direct services rendered in the crèches, namely the needs of the preschool children, the needs of the personnel of the crèches, needs regarding the physical aspects and needs of the parents.

With regard to the preschool children, parents felt that the following aspects require attention: regular visits by nurses to crèches; the teaching of the principles of Ubuntu; life skills (i.e. communication, assertiveness skills, improvement of self-esteem, etc.); sexuality issues (how to look after your body, awareness of molestation, etc.); health issues (what a balanced diet is and the importance of exercises, etc.); and lastly the safety precautions must be upgraded.

With regard to staff members, parents suggested the following: increases in salaries, further training of personnel and regular contact with, and feedback to, parents about their children's strengths and weaknesses. 
The needs regarding facilities and material are: need for after-school centres, more educational equipment, upgrading of security precautions, computer centres and sick-bays.

Parents were of the opinion that they need improvement in communication skills and especially English literacy classes. The parents also mentioned the involvement and participation of parents in the crèches as a need. Lastly, the parents felt that the crèches must be accessible to parents with low income and that the school fees must be reduced if there was more than one child from a family in a crèche.

It is interesting to note that parents were of the opinion that these needs can be addressed either through awareness campaigns, educational or training programmes and, lastly, support networks.

\section{Theme 2: Community leadership}

The parents were outspoken about the low quality and lack of effective leaders in the community. They felt that the leaders are corrupt, that they are not respected and trusted by the community, that they are not role models for them and their children, and that they need to improve their leadership skills in order to improve their community.

The required characteristics and qualities which they felt very strongly about were, amongst others, trustworthiness, love, care and respect for people, self-discipline, commitment, loyalty, being non-judgemental, flexibility, humbleness, fairness and integrity. Without the above personal leadership characteristics and skills, they could have no impact in any community (Covey, 1994; Smith, 1994).

Community leaders should be skilled in the following:

- Communication, which is divided into two sub-categories, namely general communication (like relationship building, teamwork and meeting skills) and specialised communication skills (like mediation, negotiation, conflict resolution and training skills);

- Skills in project management, with an emphasis on the ability to sustain projects;

- Leadership skills, with the aim to be a role model for the community and to empower the community members towards sustainable projects;

- Marketing skills, with an emphasis on writing proposals to sponsors, liasing and networking.

These skills compare with the skills highlighted in the literature on community development programmes and projects (Burkey, 1993; De Beer \& Swanepoel, 1996, 1998; Kotze, 1997; Swanepoel, 1997; Swanepoel \& De Beer, 1996a, 1996b).

\section{Theme 3: Family service needs}

The needs of families can be divided into four main areas: roles, structures and relationships as one area; secondly, the enhancement of life skills and important values of the child and parent; thirdly, health issues; and lastly, educational needs for children and parents.

The enhancement of communication and relationships, which are based on trust, was one of the main needs of the parents. At the same time they were also concerned about how to discipline their children without harming the relationship. Parents also felt that they spent too little time with their children and when they are with them they do not know how to play and socialise with their children. Single parenthood, the role of grandparents and the enhancement of religion and spirituality in the family were also needs emphasised in the interviews. 
The second category has to do with the needs of parents and children to develop basic life skills such as assertiveness, motivation, problem solving, conflict handling, etc. The parents were also outspoken about the establishment of sound values and principles among both adults and children, such as honesty, loyalty, commitment and trust. Parents highly recommended the establishment of parent support groups.

The parents especially expressed a deep interest in the education of their children and the need for information about the guidance of their children's career development and studies. They also need education in legal issues like female (gender) and family issues, and human rights.

Lastly, they need to be educated in financial management (how to budget and how to do financial planning). They also need information concerning study policies and bursaries for themselves and their children.

\section{Theme 4: Special needs}

The following six special needs were identified as important for ASHA's future programmes: HIV/Aids; disability; crime and violence; illiteracy; poverty; and substance abuse.

\section{HIV/Aids}

The main problem was that people are uninformed in general about issues related to sexuality. There appears to be ignorance regarding the prevalence of sexually transmitted diseases, sexual abuse, teenage pregnancies and rape in the community. Methods or ways to address these problems are, on a preventative basis, through sex education, life-skills training and information, and, on a therapeutic basis, counselling is also suggested. Parents also felt that support groups can be established to help people cope with this disease.

It is interesting to note that in the study done in $199727 \%$ of Sowetans didn't know what Aids was, in comparison with the respondents in this study, where all the respondents did know (Morris, 1999:38). The reason for this could be that ASHA was in a process of formulating an HIV/Aids policy for their centres where the parents were involved in. According to Statistics South Africa (1998:25) it was found that the higher the level of formal education, the greater the knowledge levels regarding HIV/Aids.

Of all respondents in this study, 28\% indicated that they knew HIV-positive persons, whilst $8 \%$ indicated that they had HIV-positive persons in their extended family. In terms of what they needed most to be of assistance to HIV sufferers, $25 \%$ indicated they needed information about services and $22 \%$ needed assistance and emotional support from the community.

\section{Disability}

Respondents generally expressed an intense sympathy for disabled persons. The types of disabilities prevalent in the community are mental and physical disabilities, blindness, deafness and muteness. Physical disability is often the result of polio, strokes and arthritis, according to the parents. Parents felt that disabled people needed training and job-creation skills, and the establishment of special schools was also recommended.

\section{Crime and violence}

The most prevalent types of crime and violence are emotional and physical abuse, rape, hijacking, robbery, killings, delinquency, burglary and assault. A greater police presence by employing more 
police officers, and the establishment of educational, recreational and sport facilities and programmes for both adults and children are seen as possible solutions to the problem.

Regarding the study done in 1997 , the forms of crime or violence that worried Sowetans most were rape (identified by $34,1 \%$ of respondents) and murder (identified by $26,4 \%$ of respondents) (Morris, 1999:44). The fact that rape and murder were the crimes that residents were most worried about is disturbing and suggests that extreme violence is an ever-present possibility in Soweto. This study also showed that the respondents residing in private housing domains were less worried about murder than other groupings. The reason for this is that those people were less vulnerable because of better security systems. That could be also the reason why the respondents of this study indicated other types of crime and violence as worse than murder.

\section{Illiteracy}

Parents felt strongly that they need to improve their English literacy and they recommended literacy classes in this respect. They also felt that literacy classes could be presented to illiterate people in Soweto. According to the study done in 1997, and as already mentioned, the illiteracy rate in Soweto was $10,5 \%$, while $16,2 \%$ of the population only had qualifications between Grade 3 and 6 (Department of Sociology Wits, 1997:9).

\section{Poverty}

The respondents saw poverty and unemployment as very big problems in Soweto and were of opinion that many problems (as discussed in this article) exist due to these two problems. No questions about income were asked, because ASHA thought that the respondents would not be honest in this regard. However, the statistics of Morris (1999:10) indicated that one in six households in this private housing sector had a monthly income of below R1500, six in ten said that they had a monthly income of R3000 or more, and three in ten had a monthly income above R5000 a month. If one takes all the different housing types into consideration, only one in twenty Sowetans households had an income above R5000 per month. The conclusion is indicative of a poverty-stricken community, which has an effect on all the people living in Soweto.

Parents were of opinion that poverty can be addressed by means of the employment and education of street children, workshops for unemployed people, agricultural skills training (gardens), small business and entrepreneurial skills for parents and youth, and also by establishing saving clubs.

\section{Substance abuse}

Respondents indicated that substance abuse is a huge problem in the community. Identified strategies to address this problem are counselling for parents and children who abuse alcohol and drugs, the establishment of AA support groups for people who have this problem, education of adults and children, and also awareness campaigns on alcohol and drug abuse on a preventative level.

\section{RECOMMENDATIONS}

From the results a service plan for each crèche was formulated in collaboration with staff and representatives of families of the crèches. The medium-term five-year plan is to transform all 40 crèches into self-sustainable community service centres that require limited input from ASHA management. In the short term the staff members and some of the parents of all the crèches are being trained and coached in empowerment and capacity-building skills. The training of 105 principals and parents in community leadership skills is being conducted by the Department of 
Social Work at RAU. Family Life Centre, a non-governmental organisation, has responded by training 150 parents in parenting and family preservation skills, whilst a consultant is training staff members of all the crèches on financial management aspects. Two honours students in Social Work are facilitating the implementation of the knowledge in practice during their internship. It is also realised that the coaching process that will facilitate implementation of skills and knowledge is a long-term strategy that has to be followed continuously to achieve the desired outcome.

The following general structure has been decided on for all crèches (Figure 1):

Vision: To improve the quality of life of young children and their families through an integrated and sustainable development programme.

FIGURE 1

STRUCTURE OF SERVICE PLAN

\begin{tabular}{|c|c|c|c|c|c|}
\hline \multicolumn{6}{|c|}{ 4. Special Delivery Programmes } \\
\hline HIV/Aids & $\begin{array}{l}\text { Special needs } \\
\text { Disability }\end{array}$ & $\begin{array}{l}\text { Crime and } \\
\text { violence }\end{array}$ & Illiteracy & Poverty & $\begin{array}{c}\text { Sub-stance } \\
\text { abuse }\end{array}$ \\
\hline \multicolumn{6}{|c|}{$\begin{array}{l}\text { Empowering families with skills to enable them to function as healthy, productive } \\
\text { units in the community. }\end{array}$} \\
\hline & \multicolumn{4}{|c|}{$\begin{array}{l}\text { 2. Community leadership programme } \\
\text { Building the capacity of parent committees to be able to } \\
\text { fulfil their leadership roles in the community. }\end{array}$} & \\
\hline & & $\begin{array}{l}\text { 1. Dir } \\
\text { Care and }\end{array}$ & $\begin{array}{l}\text { ervice } \\
\text { lopment. }\end{array}$ & & \\
\hline
\end{tabular}

\section{CONCLUSION}

This research has clearly shown that the targeted community is in need of community development services. It is a community that is mostly poor and only in the beginning stages of empowerment. This research project has shown that community involvement and participation is a very important variable in the outcomes of projects and that ownership is promoted when the target group is part of the solution-finding process. ASHA's vision to improve the quality of life of preschool children and their families by building their capacities through an integrated and sustainable development programme is certainly an important step towards addressing the needs of the people. By including as many people as possible from the target group, the participants felt empowered and willing to take responsibility for the various programmes indicated in the service plan.

\section{REFERENCES}

ASHA. 1999. Introductory document to business plans. Johannesburg: ASHA Management.

BERG, B.L. 1995. Qualitative research methods for the social sciences. Boston: Allyn \& Bacon.

BLESS, C. \& HIGSON-SMITH, C. 1995. Fundamentals of social research methods, an African perspective. $\left(2^{\text {nd }}\right.$ ed) Kenwyn: Juta \& Co, Ltd. 
BURKEY, S. 1993. People first, a guide to self-reliant participatory development. London: Zed Books.

CARTER, B. \& McGOLDRICK, M. 1989. The changing family life cycle: a framework for family therapy. $\left(2^{\text {nd }}\right.$ ed) New York: Allyn \& Bacon.

COVEY, S.R. 1994. Seven habits of highly effective people. London: Simon \& Schuster.

CRESWELL, J.W. 1994. Research design, qualitative and quantitative approaches. Newbury Park, CA: Sage Publications.

DE BEER, F. \& SWANEPOEL, J. 1996. Training for development. Johannesburg: Thomson.

DE BEER, F. \& SWANEPOEL, J. 1998. Community development and beyond: issues, structures and procedures. Pretoria: J.L. van Schaik.

DENZIN, N. \& LINCOLN, Y.S. 1994. Handbook of qualitative research. London: Sage.

DEPARTMENT OF SOCIOLOGY 1997. Change and continuity: a survey of Soweto in the late 1990s. Johannesburg: Wits University.

DE VOS, A. (ed) 1998. Research at grass roots, a primer for the caring professions. Pretoria: Van Schaiks.

GIORGI, A. (ed) 1985. Phenomenology and psychological research. Pittsburg, P.A.: Duquesne University Press.

GOVERNMENT GAZETTE 1999. Financing Policy: Developmental Social Welfare Services. Vol. 405, No. 19888 of 26 March 1999. Pretoria: Department of Welfare.

HAGGIE, D. 1994. Madam chair and the house at large, the story of ASHA. Johannesburg: ASHA.

KERLINGER, F.N. 1986. Foundations of behavioural research. ( $3^{\text {rd }}$ ed $)$ Chicago: Holt, Rinehart \& Winston.

KOTZÉ, D.A. 1997. Development administration and management. Pretoria: JL van Schaik.

MARSHALL, C. \& ROSSMAN, G.B. 1995. Designing qualitative research. $\left(2^{\text {nd }}\right.$ ed) Sage: London.

MORRIS, A. (ed) 1999. Change and continuity, a survey of Soweto in the late 1990s. Department of Sociology, University of the Witwatersrand: Johannesburg.

SMITH, H.W. 1994. The $\mathbf{1 0}$ natural laws of successful time and life management. London: Allen \& Unwin.

STATISTICS SOUTH AFRICA 1998. The people of South Africa: Population Census, 1996, Report No. 1. Pretoria: Statistics South Africa.

SWANEPOEL, H. 1997. Community development, putting plans into action. Kenwyn: Juta \& Co, Ltd.

SWANEPOEL, H. \& DE BEER, F. 1996a. Community capacity building, a guide for fieldworkers and community leaders. Johannesburg: Thomson.

SWANEPOEL, H. \& DE BEER, F. 1996b. Communication for development, a guide for fieldworkers. Johannesburg: Thomson. 